\title{
Perbedaan Motivasi Belajar Siswa yang Menggunakan Media Evaluasi Pembelajaran Quizizz dengan Media Evaluasi Pembelajaran Konvensional
}

\author{
Sofiatul Asral ${ }^{1}, \mathbf{R}$ Chandra $^{1^{*}}$ \\ ${ }^{1}$ Jurusan Teknik Otomotif, Universitas Negeri Padang \\ Jln. Prof. Dr. Hamka Air Tawar Padang 25131 INDONESIA \\ *e-mail: rchandra@ft.unp.ac.id \\ (Diajukan: 24 April 2021, direvisi: 30 Mei 2021, disetujui: 1 Juni 2021)
}

\begin{abstract}
Abstrak
Tujuan dari penelitian ini adalah mengetahui apakah terdapat perbedaan motivasi belajar siswa yang menggunakan media evaluasi pembelajaran quizizz dengan media evaluasi pembelajaran konvensional. Jenis penelitian ini adalah Quasi Experiment dengan desain Nonequivalent Control Group Design. Berdasarkan hasil penelitan data ke dua sampel berdistribusi normal karena nilai signifikansi (sig) $>0,05$. Ke dua sampel pada penelitian ini homogen karena harga $\mathrm{F}$ hitung $(1,681)<\mathrm{F}$ tabel $(2,271)$. Pada uji hipotesis didapatkan harga $t_{\text {hitung }}(0,69)$ lebih kecil dari $t_{\text {tabel }}(2,03)$. Maka pada penelitian ini Ho diterima dan Ha ditolak, yang artinya tidak terdapat perbedaan yang signifikan antara motivasi belajar siswa yang menggunakan media evaluasi pembelajaran quizizz dengan siswa yang menggunakan media evaluasi pembelajaran konvensional.
\end{abstract}

Kata Kunci: Media evaluasi pembelajaran, Quizizz, Konvensional, Motivasi Belajar.

\begin{abstract}
The purpose of this study is to determine whether there are differences in student learning motivation using quizizz learning evaluation media with conventional learning evaluation media. This type of research is a Quasi Experiment design with Nonequivalent Control Group Design. Based on the results of research, the data for the two samples are normally distributed because the significance value (sig)>0.05. The two samples in this study are homogeneous because the value of $F$ count (1.681) $<F$ table (2.271). In the hypothesis test, the value tcount (0.69) is smaller than t table (2.03). So in this study Ho is accepted and $\mathrm{Ha}$ is rejected, which means that there is no significant difference between student learning motivation using quizizz learning evaluation media and students using conventional learning evaluation media.
\end{abstract}

Keywords: Learning evaluation media, Quizizz, Conventional, Learning Motivation 


\section{PENDAHULUAN}

Perkembangan teknologi informasi dan komunikasi pada saat ini sangatlah pesat, dalam dunia pendidikan saja pembelajaran sudah banyak menggunakan media pembelajaran berbasis e-learning. Dengan e-learning proses pembelajaran menjadi sangat mudah dan efisien, karena dapat dilakukan di sekolah maupun di rumah, sehingga waktu evaluasi tidak terikat pada jam pembelajaran saja.

Salah satu media yang bisa digunakan sebagai evaluasi pembelajaran berbasis $e$ learning yaitu quizizz. Quizizz adalah sebuah web tools yang dapat membuat permainan kuis interaktif untuk dipakai pada saat pembelajaran di kelas. Bersifat online, menyenangkan serta bisa langsung kita peroleh hasilnya. Selain itu quizizz dapat memberikan data statistik tentang kinerja siswa dan kita sebagai guru dapat mendownload data statistik ini dalam bentuk spreadsheet excel.

Saat sekarang ini hampir semua sekolah telah memiliki laboratorium komputer dan jaringan internet yang bisa dimanfaatkan untuk mendukung adanya evaluasi pembelajaran yang memanfaatkan teknologi. Selain itu hampir seluruh siswa dan guru sudah memiliki smartphone dan laptop yang memiliki jaringan internet sendiri, hal ini sangat mendukung dan memudahkan guru dalam melakukan evaluasi pembelajaran berbasis e-learning.

Berdasarkan observasi pada saat melaksanakan PLK pada semester Juli-Desember 2019, penulis menemukan hampir seluruh siswa melakukan kecurangan ketika mengerjakan soal, ada yang menyontek, memberikan contekan dan bahkan ada yang melihat buku dan smartphone. Siswa yang mencontek menunjukkan perilaku motivasi belajar yang rendah sehingga dapat menemui berbagai macam kesulitan dalam belajar, selain itu siswa yang motivasi belajarnya rendah memiliki tingkat pemahaman yang tidak memadai dalam menyelesaikan tes [1]. Hal negatif tersebut sebenarnya dapat dialihkan ke hal yang positif yaitu dengan memanfaatkan media evaluasi pembelajaran yang berbasis e-learning ini.

Dengan memanfaatkan media evaluasi pembelajaran berbasis e-learning diharapkan dapat meningkatkan motivasi belajar siswa, dan membantu guru dalam penilaian hasil belajar siswa. Selain itu juga diharapkan siswa dapat menggunakan smartphone ke hal yang positif sebagai penunjang proses pembelajaran. Sehingga dapat mengurangi terjadinya kecurangan dalam kegiatan evaluasi pembelajaran. Berdasarkan uraian di atas, penulis ingin melakukan penelitian dengan judul Perbedaan Motivasi Belajar Siswa yang Menggunakan Media Evaluasi Pembelajaran Quizizz dengan Media Evaluasi Pembelajaran Konvensional Pada Mata Pelajaran Pekerjaan Dasar Teknik Otomotif di SMK Negeri 2 Payakumbuh.

\section{Definisi Media}

Media adalah sesuatu yang digunakan sebagai alat, perantara, dan sarana dalam proses komunikasi [2].

\section{Evaluasi Pembelajaran}

1. Definisi Evaluasi Pembelajara

Evaluasi pembelajaran digunakan untuk mengumpulkan informasi supaya dapat mengetahui perkembangan, kemajuan, pencapaian belajar siswa, dan keefektifan pengajaran guru [3].

2. Tujuan Evaluasi Pembelajaran

Tujuan evaluasi pembelajaran yaitu untuk mengetahui keefektifan sistem pembelajaran yang menyangkut tujuan, materi, metode, media, sumber belajar, lingkungan dan sistem penilaian [4]. 


\section{Motivasi Belajar}

1. Definisi Motivasi Belajar

Motivasi belajar yaitu adanya suatu dorongan internal dan eksternal pada diri siswa dalam belajar untuk melakukan perubahan tingkah laku melalui beberapa indikator dan unsur yang mendukung [5].

2. Fungsi Motivasi Belajar

Fungsi motivasi dalam belajar yaitu (a)Mendorong manusia agar berbuat dalam setiap kegiatan yang akan dikerjakan (b)Menentukan arah serta perbuatan ke tujuan yang akan dicapai (c)Menyeleksi perbuatan bermanfaat mana yang harus dikerjakan dan yang harus disisihkan untuk mencapai tujuan [6].

\section{Mata Pelajaran Pekerjaan Dasar Teknik Otomotif (PDTO)}

Pekerjaan Dasar Teknik Otomotif (PDTO) adalah suatu pelajaran yang mencakup pembahasan tentang ilmu dasar teknik otomotif yaitu tentang peralatan-peralatan kerja yang digunakan di bengkel otomotif. Pembelajarannya mencakup tentang pengenalan alat, bagaimana cara penggunaan alat, dan cara perawatan alat tersebut. Di dalam pelajaran Pekerjaan Dasar Teknik Otomotif ini terdapat beberapa materi pembelajaran diantaranya adalah hand tools, power tools, spesial service tools dan lain sebagainya. Sehingga dengan mempelajari Pekerjaan Dasar Teknik Otomotif ini siswa dapat mengenali, menggunakan, serta merawat peralatan-peralatan kerja yang ada di bengkel otomotif.

\section{Media Evaluasi Pembelajaran Konvensional}

Media evaluasi pembelajaran konvensional adalah media yang digunakan oleh guru selama ini untuk melakukan penilaian atau evaluasi pembelajaran. Penilaian pada media konvensional dilakukan dengan cara tes tertulis dengan memanfaatkan kertas dan alat tulis.

\section{Quizizz}

Quizizz adalah sebuah web tools yang dapat membuat permainan kuis interaktif untuk dipakai pada saat pembelajaran di kelas. Bersifat online, menyenangkan serta bisa langsung kita peroleh hasilnya. Selain itu quizizz dapat memberikan data statistik tentang kinerja siswa dan kita sebagai guru dapat mendownload data statistik ini dalam bentuk spreadsheet excel.

\section{METODE}

Metode pada penelitian ini yaitu metode Quasi Experiment. Quasi Experiment merupakan desain yang memiliki kelempok kontrol, tapi tidak bisa berfungsi sepenuhnya untuk megontrol variabel-variabel luar yang mepengaruhi pelaksanaan eksperimen [7]. Desain penelitian yang dipakai pada penelitian ini yaitu Nonequivalent Control Group Design.

Peneliti menggunakannya karena kelompok penelitian tidak diambil secara random.. Disini peneliti memilih satu kelas untuk dijadikan populasi penelitian. Selanjutnya satu kelas tersebut dibagi menjadi dua kelompok, sehingga terdapat dua sampel penelitian. Kemudian pada kedua kelompok tersebut diberikan pretest berupa angket untuk mengetahui motivasi belajar siswa sebelum diberikan perlakuan. Selanjutnya diberikan perlakuan (treatment) berupa tes menggunakan media evaluasi pembelajaran quizizz pada kelompok eksperimen dan memberikan perlakuan (treatment) 
berupa tes dengan menggunakan evaluasi pembelajaran secara konvensional pada kelompok kontrol.

Perlakuan disini diberikan sebanyak tiga kali pada setiap kelompok. Dan setelah itu peneliti memberikan posttest berupa angket untuk mengetahui motivasi belajar siswa setelah diberi perlakuan pada kedua kelompok tersebut. Sehingga nantinya dapat diketahui apakah tetdapat perbedaan motivasi belajar siswa yang menggunakan media evaluasi pembelajaran quizizz dengan yang menggunakan media evaluasi pembelajaran konvensional.

\section{HASIL DAN PEMBAHASAN}

\section{Hasil}

Tabel 1. Hasil Perhitungan Statistik Motivasi Belajar

\begin{tabular}{lcccc}
\hline & $\begin{array}{c}\text { Motivasi awal } \\
\text { kelompok } \\
\text { eksperimen }\end{array}$ & $\begin{array}{c}\text { Motivasi akhir } \\
\text { kelompok } \\
\text { eksperimen }\end{array}$ & $\begin{array}{c}\text { Motivasi awal } \\
\text { kelompok kontrol }\end{array}$ & $\begin{array}{c}\text { Motivasi akhir } \\
\text { kelompok kontrol }\end{array}$ \\
\hline Mean & 18 & 18 & 18 & 18 \\
Valid & 0 & 0 & 0 & 0 \\
Std. Error of Mean & 129.56 & 136.44 & 130.28 & 131.39 \\
Median & 1.824 & 2.563 & 2.739 & 1.977 \\
Mode & 130.00 & 136.50 & 129.50 & 130.00 \\
Std. Deviation & 125 & 131 & $118^{\mathrm{a}}$ & 126 \\
Variance & 7.740 & 10.875 & 11.620 & 8.389 \\
Range & 59.908 & 118.261 & 135.036 & 70.369 \\
Minimum & 30 & 43 & 43 & 28 \\
Maximum & 110 & 114 & 106 & 120 \\
\hline Sum & 140 & 157 & 149 & 148 \\
\hline a. Multiple modes exist. The smallest value is shown & 2456 & 2345 & 2365 \\
\hline \multicolumn{5}{l}{} \\
\hline
\end{tabular}

Menurut tabel 1 menjelaskan hasil perhitungan statistik motivasi belajar dari kelompok eksperimen dan kelompok kontrol. Motivasi awal kelompok eksperimen yaitu N sebanyak 18, Mean/rata-rata 129.56, Median 130.00, Mode/Modus 125, Standar Deviasi 7.740, Varian 59.908, Range 30, Minimum 110, Maksimum 140, dan Sum/skor keseluruhan 2332. Motivasi akhir kelompok eksperimen yaitu $\mathrm{N}$ sebanyak 18, Mean/rata-rata 136.44, Median 136.50, Mode/Modus 131, Standar Deviasi 10.875, Varian 118.261, Range 43, Minimum 114, Maksimum 157, dan Sum/skor keseluruhan 2456. Motivasi awal kelompok kontrol yaitu N sebanyak 18, Mean/rata-rata 130.28, Median 129.50, Mode/Modus 118, Standar Deviasi 11.620, Varian 135.036, Range 43, Minimum 106, Maksimum 149, dan Sum/skor keseluruhan 2345. Dan motivasi akhir kelompok kontrol yaitu N sebanyak 18, Mean/rata-rata 131.39, Median 130.00, Mode/Modus 126, Standar Deviasi 8.389, Varian 70.369, Range 28, Minimum 120, Maksimum 148, dan Sum/skor keseluruhan 2365 
Tabel 2. Hasil Uji Normalitas

\begin{tabular}{|c|c|c|c|c|c|c|}
\hline & \multicolumn{3}{|c|}{ Kolmogorov-Smirnov $^{\mathrm{a}}$} & \multicolumn{3}{|c|}{ Shapiro-Wilk } \\
\hline & Statistic & df & Sig. & Statistic & df & Sig. \\
\hline $\begin{array}{l}\text { Motivasi awal kelompok } \\
\text { eksperimen }\end{array}$ & .148 & 18 & $.200^{*}$ & .921 & 18 & .135 \\
\hline $\begin{array}{l}\text { Motivasi akhir kelompok } \\
\text { eksperimen }\end{array}$ & .086 & 18 & $.200^{*}$ & .985 & 18 & .986 \\
\hline $\begin{array}{l}\text { Motivasi awal kelompok } \\
\text { kontrol }\end{array}$ & .100 & 18 & $.200^{*}$ & .969 & 18 & .772 \\
\hline $\begin{array}{l}\text { Motivasi akhir kelompok } \\
\text { kontrol }\end{array}$ & .130 & 18 & $.200^{*}$ & .948 & 18 & .400 \\
\hline *. This is a lower bound $\mathrm{c}$ & significance & & & & & \\
\hline icance & & & & & & \\
\hline
\end{tabular}

Menurut tabel 2 nilai sig masing-masing yaitu motivasi awal kelompok eksperimen 0,135, motivasi akhir kelompok eksperimen 0,986, motivasi awal kelompok kontrol 0,772, motivasi akhir kelompok kontrol 0,400. Dasar pengambilan keputusan uji normalitas Shapiro-Wilk menggunakan kualifikasi yaitu (a) Apabila nilai sig < 0,05, maka data tidak berdistribusi normal (b)Apabila nilai sig $>0,05$, maka data berdistribusi normal. Dengan demikian dapat dikatakan bahwa data motivasi belajar kelompok eksperimen dan kelompok kontrol berdistribusi normal, karena nilai signifikansi (sig) > 0,05 .

Tabel 3. Hasil Uji Homogenitas

\begin{tabular}{|c|c|c|}
\hline & Kelompok Eksperimen (X1) & Kelompok Kontrol (X2) \\
\hline $\mathbf{N}$ & 18 & 18 \\
\hline Dk (n-1) & 17 & 17 \\
\hline Varian & 118.261 & 70.369 \\
\hline Fhitung & \multicolumn{2}{|c|}{$118.261 / 70.369=1.681$} \\
\hline Ftabel & \multicolumn{2}{|c|}{2.272} \\
\hline Hasil & \multicolumn{2}{|c|}{ Homogen } \\
\hline
\end{tabular}

Kriteria pengujian homogenitas yaitu (a) Jika $F_{\text {hitung }}>F_{\text {tabel }}$, maka data tidak homogen (b)Jika $F_{\text {hitung }}<F_{\text {tabel }}$, maka data homogeny. Dari hasil uji homogenitas dapat dikatakan bahwa kedua sampel homogen karena harga $F_{\text {hitung }}$ sebesar 1,681 lebih kecil dari harga $F_{\text {tabel }}$ sebesar 2,271.

Tabel 4. Data Uji Hipotesis

\begin{tabular}{lcc}
\hline No & Kelompok Eksperimen $(\mathbf{X 1})$ & Kelompok Kontrol (X2) \\
\hline 1 & 125 & 126 \\
2 & 157 & 126 \\
3 & 136 & 122 \\
4 & 144 & 134 \\
5 & 155 & 148 \\
6 & 143 & 129 \\
7 & 129 & 122 \\
8 & 139 & 121 \\
9 & 135 & 141 \\
10 & 141 & 138
\end{tabular}




\begin{tabular}{ccc}
\hline No & Kelompok Eksperimen (X1) & Kelompok Kontrol (X2) \\
\hline 11 & 131 & 126 \\
12 & 137 & 120 \\
13 & 138 & 140 \\
14 & 114 & 144 \\
15 & 133 & 129 \\
16 & 147 & 131 \\
17 & 131 & 131 \\
18 & 121 & 137 \\
\hline $\mathbf{n}$ & 18 & 18 \\
\hline$\overline{\boldsymbol{X}}$ & 136.44 & 131.39 \\
\hline $\mathbf{S}$ & 10.875 & 8.389 \\
\hline $\boldsymbol{S}^{\mathbf{2}}$ & 118.261 & 70.369 \\
\hline
\end{tabular}

Menurut tabel 4 maka diperoleh hasil uji hipotesis yaitu sebagai berikut:

$$
\begin{aligned}
& t=\frac{\overline{X_{1}}-\overline{X_{2}}}{\sqrt{\frac{S_{1}{ }^{2}}{n_{1}}+\frac{S_{2}{ }^{2}}{n_{2}}\left(\frac{S_{1}}{\sqrt{n_{1}}}\right)\left(\frac{S_{2}}{\sqrt{n_{2}}}\right)}} \\
& t=\frac{136.44-131.39}{\sqrt{\frac{118,261}{18}+\frac{70,369}{18}\left(\frac{10,875}{\sqrt{18}}\right)\left(\frac{8.389}{\sqrt{18}}\right)}} \\
& t=\frac{136.44-131.39}{\sqrt{\frac{118,261}{18}+\frac{70,369}{18}\left(\frac{10,875}{4,24}\right)\left(\frac{8.389}{4,24}\right)}} \\
& t=\frac{5.05}{\sqrt{6,57+3,91(2,56)(1,98)}} \\
& t=\frac{5,05}{\sqrt{10,48(5,06)}} \\
& t=\frac{5,05}{\sqrt{53.02}} \\
& t=\frac{5,05}{7,28} \\
& t=\frac{5,05}{7,28} \\
& t=0,69
\end{aligned}
$$

Setelah didapatkan harga $t_{\text {hitung, }}$, selanjutnya bandingkan dengan harga $t_{\text {tabel }}$ dengan $d k=n_{1}+n_{2}-2=18+18-2=34$. Dengan taraf kesalahan 0,05 maka didapatkan harga $t_{\text {tabel }}=2,03$. Kriteria pengujia hipotesis yaitu (a)Jika $t_{\text {hitung }} \leq t_{\text {tabel }}$ maka hipotesis nol (Ho) diterima dan hipotesis alternatif (Ha) ditolak (b)Jika $t_{\text {hitung }}>$ $t_{\text {tabel }}$ maka hipotesis nol (Ho) ditolak dan hipotesis alternatif (Ha) diterima.

Jadi dapat disimpulkan bahwa harga $t_{\text {hitung }} 0,69$ lebih kecil dari $t_{\text {tabel }} 2,03$. Maka pada penelitian ini hipotesis nol (Ho) diterima dan hipotesis alternatif (Ha) 
ditolak. Yang artinya tidak terdapat perbedaan yang signifikan antara motivasi belajar siswa yang menggunakan media evaluasi pembelajaran quizizz dengan siswa yang menggunakan media evaluasi pembelajaran konvensional pada mata pelajaran Pekerjaan Dasar Taknik Otomotif di SMK Negeri 2 Payakumbuh.

\section{Pembahasan}

Penelitian terbagi menjadi dua kelompok yaitu kelompok eksperimen dan kelompok kontrol. Kelompok eksperimen diberikan perlakuan (treatment) meggunakan media evaluasi pembelajaran quizizz dan kelompok kontrol diberikan perlakuan (treatment) mrnggunakan media evaluasi pembelajaran konvensional. Perlakuan (treatment) diberikan diberikan sebanyak 3 kali pada masing-masing kelompok.

Dari hasil penelitian didapatkan rata-rata motivasi belajar kelompok eksperimen sebelum diberikan perlakuan (treatment) yaitu 129,56, dan setelah diberikan perlakuan (treatment) yaitu 136,44. Jadi setelah diberikan perlakuan (treatment), motivasi belajar siswa yang menggunakan media evaluasi pembelajaran quizizz naik sebesar 6,88\%.

Sedangkan pada kelompok kontrol rata-rata motivasi belajar kelompok kontrol sebelum diberikan perlakuan (treatment) yaitu 130,28, dan setelah diberikan perlakuan (treatment) yaitu 131,39. Jadi setelah diberikan perlakuan (treatment), motivasi belajar siswa yang menggunakan media evaluasi pembelajaran konvensional naik sebesar $1,11 \%$.

Jika dibandingkan rata-rata motivasi belajar antara kelompok eksperimen dan kelompok kontrol setelah diberikan perlakuan (treatment) terdapat perbedaan motivasi belajar sebesar 5,05\%. Yang mana motivasi belajar kelompok eksperimen yaitu 136,44 dan kelompok kontrol 131,39.

Setelah dilakukan uji hipotesis dengan menggunakan Uji T didapat $t_{\text {hitung }} 0,69$ dan $t_{\text {tabel }} 2,03$ berarti $t_{\text {hitung }}<t_{\text {tabel }}$, maka dapat disimpulkan bahwa hipotesis nol (Ho) diterima dan hipotesis alternatif (Ha) ditolak. Dengan kata lain tidak terdapat perbedaan yang signifikan antara motivasi belajar siswa yang menggunakan media evaluasi pembelajaran quizizz dengan siswa yang menggunakan media evaluasi pembelajaran konvensional pada mata pelajaran Pekerjaan Dasar Teknik Otomotif di SMK Negeri 2 Payakumbuh.

\section{KESIMPULAN DAN SARAN}

\section{Kesimpulan}

Berdasarkan hasil penelitian perbedaan motivasi belajar siswa yang menggunakan media evaluasi pembelajaran quizizz dengan media evaluasi pembelajaran konvensional pada mata pelajaran Pekerjan Dasar Teknik Otomatif di SMK Negeri 2 Payakumbuh. Dari hasil didapatkan media evaluasi pembelajaran quizizz memberikan pengaruh sebesar $6,88 \%$ dan media evaluasi pembelajaran konvensional sebesar1,11\%. Setelah diberikan perlakuan pada masing-masing kelompok maka terdapat perbedaan motivasi belajar sebesar 5,05\%. Setelah dilakukan uji hipotesis didapatkan hasil didapat $t_{\text {hitung }}$ 0,69 dan $t_{\text {tabel }} 2,03$ berarti $t_{\text {hitung }}<t_{\text {tabel }}$ atau hipotesis nol (Ho) diterima dan hipotesis alternatif (Ha) ditolak. Hal ini berarti bahwa tidak terdapat perbedaan yang signifikan antara motivasi belajar siswa yang menggunakan media evaluasi 
pembelajaran quizizz dengan siswa yang menggunakan media evaluasi pembelajaran konvensional pada mata pelajaran Pekerjaan Dasar Teknik Otomotif di SMK Negeri 2 Payakumbuh.

\section{Saran}

Berdasarkan pada kesimpulan di atas, maka dapat diperoleh saran-saran sebagai berikut: Saran pertama penulis menyarankan untuk meningkatkan motivasi belajar siswa, guru di sekolah dapat menggunakan media evaluasi pembelajaran quizizz. Atau bisa menggunakan media evaluasi pembelajaran lain yang bisa menigkatkan motivasi belajar lebih dari media evaluasi pembelajaran quizizz dan konvensional. Saran kedua penulis berharapan dengan hasil penelitian ini semoga penelitian ini dapat dijadikan sebagai bahan referensi bagi peneliti yang akan datang.

\section{REFERENSI}

[1] Hartanto, Dody. 2010. Bimbingan \& Konseling Menyontek: Mengungkap Akar Masalah dan Solusinya. Jakarta Barat: Indeks.Sanjaya, Wina. 2013. Kurikulum Dan Pembelajaran. Jakarta: Kencana Perdana Group.

[2] Rohani, Ahmad. 2007. Media Instruksional Edukatif. Jakarta: Raja Grafindo Persada.

[3] Ratnawulan \& Rusdiana. 2014. Evaluasi Pembelajaran:Dengan Pendekatan Kurikulum 2013. Bandung: Pustaka Setia

[4] Arifin, Zainal. 2012. Evaluasi Pembelajaran:Prinsip-Teknik-Prosedur. Bandung: Remaja Rosdakarya.

[5] Uno, Hamzah B. 2012. Teori Motivasi \& Pengukurannya. Jakarta: Bumi Aksara

[6] A.M, Sardiman. 2010. Interaksi \& Motivasi Belajar Mengajar. Jakarta: Rajawali Pers.

[7] Sugiyono. 2010. Metode Penelitian Pendidikan: Pendekatan Kuantitatif, Kualitatif, dan $R \& D$. Bandung: Alfabeta. 